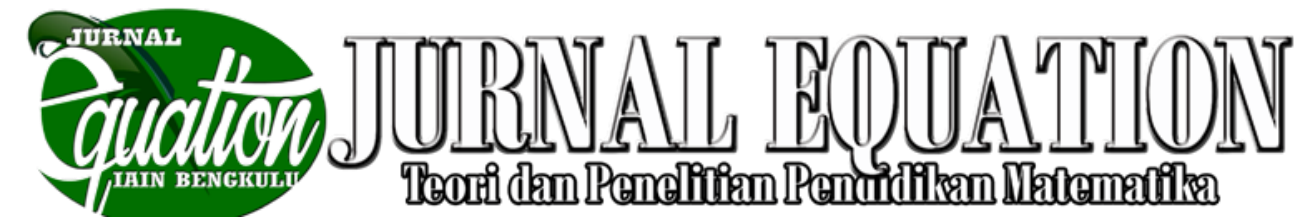

Volume 2 Nomor 2, September 2019, ISSN 2599-3291 (Cetak), ISSN 2614-3933 (Online)

\title{
Etnomatematika dalam Seni Tari Kejei Sebagai Kebudayaan Rejang Lebong
}

\author{
Sindi Destrianti ${ }^{1)}$, Saumi Rahmadani2), Tomi Ariyanto ${ }^{3)}$ \\ Fakultas Tarbiyah dan Tadris, IAIN Curup \\ sindidestriani@gmail.com
}

\begin{abstract}
ABSTRAK
Matematika adalah salah satu bentuk budaya, yang sesungguhnya telah terintegrasi pada setiap unsur kehidupan masyarakat. Budaya yang pada hakekatnya merupakan hasil pikiran dan karya manusia, mempengaruhi perilaku individu dalam memahami perkembangan pendidikan termasuk pembelajaran matematika. Salah satu budaya khas Kabupaten Rejang Lebong yang masih dilestarikan sampai saat ini adalah Tari Kejei. Tari Kejei merupakan tarian sakral dengan gerakan sederhana dan berbeda dengan gerakan pada umumnya, serta diiringi oleh alat musik khas Rejang Lebong yang memiliki alunan berulang. Penelitian ini bertujuan untuk 1) mengetahui hubungan antara alat musik pengiring dengan konsep matematika, dan 2) mengetahui hubungan gerakan Tari Kejei dengan konsep matematika. Penelitian ini merupakan penelitian deskriptif fenomenologi. Sumber data dari penelitian ini adalah Tari Kejei itu sendiri dan beberapa narasumber yaitu Ketua Adat, Pelatih Tari, dan Penari. Pengumpulan data dilakukan melalui metode observasi, wawancara, dan dokumentasi. Data tersebut dianalisis mulai dari tahap reduksi data, penyajian data, dan penyimpulan data atau verifikasi. Hasil penelitian menunjukkan bahwa 1) hubungan antara alat musik pengiring Tari Kejei dengan konsep matematika adalah bentuk alat musik berupa gong, kulintang, dan redap yang memenuhi konsep bangun ruang yaitu tabung. 2) hubungan antara gerakan Tari Kejei dengan konsep matematika diantaranya adalah konsep geometri seperti kesejajaran, garis lurus, rotasi, dilatasi, segitiga, segiempat, dan konsep pola hitungan.
\end{abstract}

Kata Kunci : Etnomatematika, Tari Kejei, Kebudayaan Rejang Lebong

PENDAHULUAN

Matematika adalah ilmu yang mempelajari tentang bentuk, besaran, dan konsep-konsep yang berkaitan satu sama lainnya. Keterkaitan tersebut tidak hanya pada matematika itu sendiri, namun matematika juga berkaitan dengan disiplin ilmu lain, salah satunya adalah budaya. Seperti hasil studi yang dilakukan oleh Bandeira dan Luceina (Puspadewi, 2016) yang memfokuskan pembelajaran matematika sekolah dan pengaruh faktor budaya pada pembelajaran matematika akademik. Selain itu juga, relevansi matematika dalam berbagai aspek kehidupan harus memahami sifat matematika yang dijadikan sebagai alat untuk menyelesaikan suatu masalah karena matematika merupakan ide-ide yang relevan, fakta, konsep, dan keterampilan yang diperoleh sebagai hasil dari konteks budaya.

Hasratuddin mengungkapkan, matematika merupakan suatu cara untuk menemukan jawaban terhadap masalah yang dihadapi manusia, suatu cara menggunakan informasi, menggunakan pengetahuan 


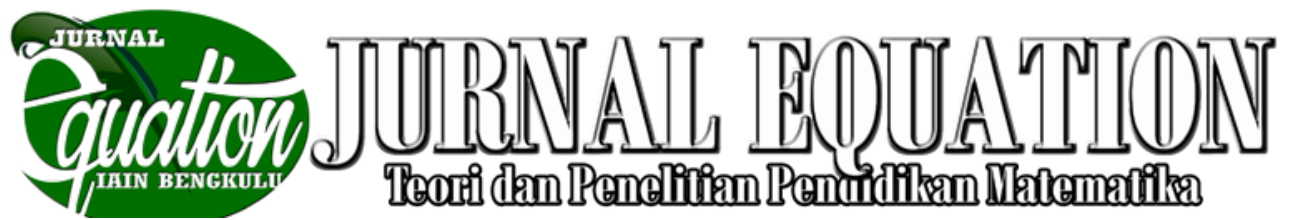

Volume 2 Nomor 2, September 2019, ISSN 2599-3291 (Cetak), ISSN 2614-3933 (Online)

tentang bentuk dan ukuran, menggunakan pengetahuan tentang menghitung, dan yang paling penting adalah memikirkan pada diri manusia itu sendiri dalam melihat dan menggunakan hubungan-hubungan (Anggita, 2018). Paradigma matematika sebagai kemampuan berpikir dan alat cenderung menggunakan pemikiran yang linear terkait dengan teorema dan rumus-rumus semata, namun jika matematika itu sendiri diintegrasikan dalam sesuatu yang softskill maka pemikiran menjadi lentur. Misalnya, bentuk-bentuk keindahan bangunanbangunan bersejarah seperti candi, artefak, prasasti, dan bangunan bersejarah lainnya. Tidak terlepas dari itu juga bangunan didesain sedemikian rupa mengunakan estetika bukan semata dari aspek bentuk geometri tiga dimensi. Berbagai hasil budaya Indonesia memperlihatkan unsur kreativitas dalam matematika.

Suparlan (Abdullah, 2016) mendefinisikan budaya sebagai keseluruhan pengetahuan manusia sebagai mahluk sosial, yang digunakan untuk menginterpretasikan dan memahami lingkungan yang dihadapi, dan untuk menciptakan dan mendorong terwujudnya kelakuan. Budaya yang menjadi warisan dari bangsa Indonesia merupakan suatu konsep yang diwujudkan secara simbolik dan nonsimbolik, nilai-nilai, keyakinan, perilaku adat, dan secara progresif memberi makna untuk mengatasi masalah yang dihadapi. Keterkaitan antara budaya dan matematika sangatlah erat, matematika melatih kemampuan berpikir kritis dan kreatif untuk menumbuh kembangkan budaya yang unggul sesuai konteks masa kini. Selain itu juga, budaya mempengaruhi perilaku individu dalam memahami perkembangan pendidikan termasuk pembelajaran matematika. Demikian juga matematika dipengaruhi oleh latar belakang budaya, karena seseorang melakukan sesuai dengan apa yang dilihat dan dirasakan.

Wahyuni dkk menyatakan bahwa salah satu yang dapat menjembatani antara budaya dan pendidikan matematika adalah etnomatematika (Astri Wahyuni, 2013). Etnomatematika terdiri atas dua kata, etno (etnis/budaya) dan matematika. Itu berarti bahwa etnomatematika merupakan matematika dalam budaya. Istilah etnomatematika diperkenalkan oleh D'Ambrosio seorang matematikawan Brazil pada tahun 1977. Secara bahasa, awalan "ethno" diartikan sebagai sesuatu yang sangat luas yang mengacu pada konteks sosial budaya, termasuk bahasa, jargon, kode perilaku, mitos, dan simbol. Kata dasar "mathema" cenderung berarti menjelaskan, mengetahui, memahami, dan melakukan kegiatan seperti pengkodean, mengukur, mengklarifikasi, menyimpulkan, dan 


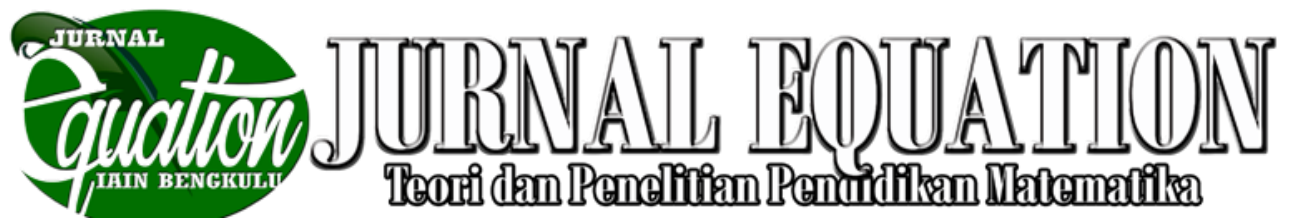

Volume 2 Nomor 2, September 2019, ISSN 2599-3291 (Cetak), ISSN 2614-3933 (Online)

pemodelan (Lusi Nofitasari, 2015)

Matematika adalah salah satu bentuk budaya, yang sesungguhnya telah terintegrasi pada setiap unsur kehidupan masyarakat. Pada dasarnya matematika merupakan ide simbolis yang tumbuh dan berkembang pada keterampilan dan aktivitas lingkungan yang berbudaya. Gagasan etnomatematika akan dapat memperkaya pengetahuan matematika yang telah ada. Oleh sebab itu, jika perkembangan etnomatematika telah banyak dikaji, maka bukan tidak mungkin matematika diajarkan dengan mengambil budaya setempat. Objek-objek yang ada di sekeliling dapat dijadikan objek etnomatematika, seperti bentuk rumah adat, pola gerak tari, alat musik tradisional, dan motif kain tradisional.

Dari bermacam macam suku dan budaya yang ada di Indonesia, terdapat suku tertua yang ada di pulau Sumatera selain suku melayu yaitu suku Rejang. Suku Rejang diyakini berasal dari daerah Sumatera bagian utara dan kemudian menyebar sampai ke daerah Lebong, Kepahiang, sampai di tepi sungai Ulu Musi yang berbatasan dengan Sumatera Selatan. Suku Rejang terbanyak terdapat di Kabupaten Rejang Lebong yang kini telah memekarkan diri menjadi Kabupaten Rejang Lebong (induk), Kabupaten Lebong, dan Kabupaten Kepahiang. Hampir semua dari unsur-unsur budaya telah dimiliki oleh suku Rejang, seperti: sejarah, bahasa, aksara, sistem pengetahuan, sistem organisasi sosial, sistem peralatan hidup, sistem religi, dan kesenian.

Berbagai kesenian yang ada di Rejang Lebong salah satunya adalah tari Kejei. Tari Kejei merupakan tarian sakral dengan gerakan sederhana dan berbeda dengan gerakan pada umumnya. Tarian ini disajikan pada waktu acara yang disebut bimbang adat atau puncak pernikahan di sebuah panggung terbuka yang dinamakan balai Kejei. Pertunjukan kebudaayan tari Kejei dibawakan oleh pemuda-pemudi yang bepasangan dalam jumlah ganjil. Awalnya, para penari menyambut kedatangan kedua mempelai dengan membawa cerano berisi sirih sebagai lambang penghormatan. Para penari mengikuti kedua mempelai bersama pihak keluarga menuju balai Kejei. Tari Kejei diiringi oleh alat musik pengiring seperti gong, kulintang, dan redap. Ketiga alat musik tradisional tersebut memiliki peran penting. Oleh sebab itu sebelum tarian dimulai gong, kulintang, dan redap disyaratkan dalam ritual temu'un gung klintang.

Elemen-elemen tari Kejei yang telah disebutkan di atas erat kaitannya dengan matematika. Konsep-konsep matematika diantaranya adalah alat musik dan gerakan tari. Dari keterkaitan yang ada, antara matematika dengan salah satu kebudayaan yang ada di Rejang Lebong yaitu tari Kejei, maka kami tertarik 


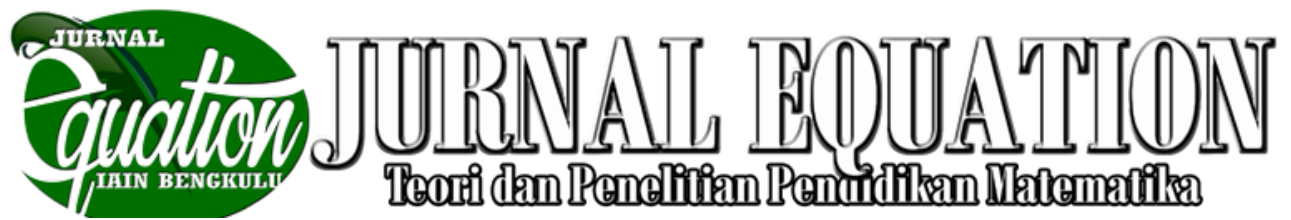

Volume 2 Nomor 2, September 2019, ISSN 2599-3291 (Cetak), ISSN 2614-3933 (Online)

untuk mengkaji matematika berbasis budaya dengan judul Etnomatematika dalam Seni Tari Kejei sebagai Kebudayaan Rejang Lebong.

Adapun tujuan dari penelitian ini adalah untuk mengetahui hubungan antara alat musik pengiring Tari Kejei dengan matematika dan mengetahui hubungan antara gerakan Tari Kejei dengan matematika.

\section{Pengertian Matematika}

James dan James menyebutkan bahwa matematika adalah ilmu tentang logika mengenai bentuk, susunan, besaran, konsepkonsep yang saling berhubungan, dan jumlah yang banyak, serta terbagi ke dalam tiga bidang, yaitu aljabar, analisis, dan geometri (Suherman \& dkk, 2003). Matematika adalah ilmu dasar yang dapat menjadi alat dalam mempelajari ilmu-ilmu yang lain. Oleh karena itu, penguasaan terhadap matematika sangat diperlukan serta konsep-konsep matematika harus dipahami dengan betul dan benar sejak dini. Suatu konsep disusun berdasarkan konsep-konsep sebelumnya, dan akan menjadi dasar bagi konsep-konsep selanjutnya, sehingga pemahaman yang salah terhadap suatu konsep, akan berakibat pada kesalahan pemahaman terhadap konsep-konsep selanjutnya (Prihandoko, 2005).

Senada dengan hal tersebut Mustafa menyebutkan bahwa:

Matematika adalah ilmu tentang kuantitas, bentuk, susunan, dan ukuran, yang utama adalah metode dan proses untuk menemukan dengan konsep yang tepat dan lambang yang konsisten, sifat, dan hubungan antara jumlah dan ukuran, baik secara abstrak, matematika murni atau dalam keterkaitan manfaat pada matematika terapan (Puspitasari, 2016)

Nasution menjelaskan bahwa matematika berhubungan dengan kepandaian seseorang, oleh karena itu diperlukan penguasaan terhadap matematika dan pemahaman konsep-konsep matematika sejak dini (Mahanani, 2018).

Maka dapat disimpulkan dari beberapa pengertian di atas bahwa matematika adalah ilmu yang mempelajari tentang konsepkonsep yang saling berkaitan dengan ilmu pengetahuan lainnya dan berkenaan dengan objek-objek abstrak, fakta, dan ide-ide yang relevan.

\section{Pengertian Budaya}

Kebudayaan menurut Edward B.Taylor adalah totalitas yang kompleks yang mencakup pengetahuan, kepercayaan, seni, hukum, moral, adat, dan kemampuankemampuan, serta kebiasaan-kebiasaan yang diperoleh orang sebagai anggota masyarakat (Pramusinta, 2013). Kebudayaan akan terus berubah sesuai dengan sejarah yang berkembang, sesuai dengan percepatan perkembangan ilmu dan pengetahuan, beserta perkembangan keterampilan manusia. Perubahan ini berasal dari tiga hal 


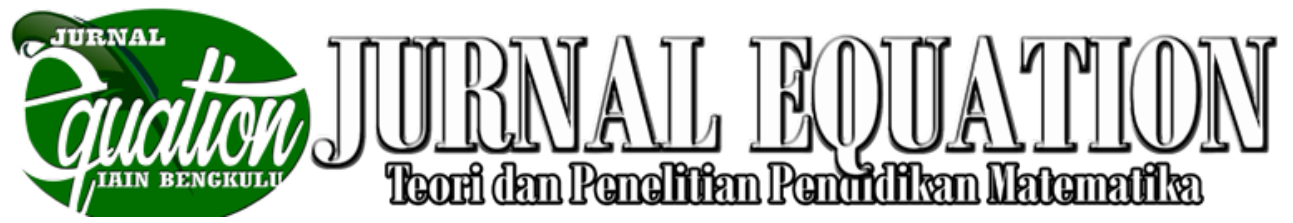

Volume 2 Nomor 2, September 2019, ISSN 2599-3291 (Cetak), ISSN 2614-3933 (Online)

yaitu, Originasi adalah sesuatu yang baru atau penemuan-penemuan yang baru. Difusi ialah pembentukan kebudayaan baru akibat masuknya elemen-elemen budaya yang baru ke dalam budaya yang lama. Reinterpretasi ialah perubahan kebudayaan akibat terjadinya modifikasi elemen-elemen kebudayaan yang telah ada agar sesuai dengan keadaan zaman. (Pramusinta, 2013)

Ditinjau dari sudut bahasa Indonesia kebudayaan berasal dari bahasa Sanskerta "Budhayah", yakni bentuk jamak dari budhi yang berarti budi atau akal (Setyawan, 2014). Kebudayaan dalam bahasa inggris disebut culture, sedangkan dalam Belanda dinamakan cultur, kemudian dalam bahasa latin colere dan wen-hus untuk bahasa Tionghoa (Rahmawati, 2015). Budaya menurut Koentjaraningrat merupakan keseluruhan sistem gagasan, tindakan, dan hasil karya manusia dalam kehidupan masyarakat yang dijadikan milik diri manusia dengan belajar (Lestari, 2015).

Begitu juga menurut Suparlan, bahwa budaya dapat diartikan sebagai

Keseluruhan pengetahuan manusia sebagai mahluk sosial, yang digunakan untuk menginterpretasikan dan memahami lingkungan yang dihadapi, dan untuk menciptakan dan mendorong terwujudnya kelakuan. Berdasarkan ilmu antropologi, budaya dapat didefinisikan sebagai keseluruhan sistem gagasan, tindakan, dan hasil karya manusia dalam rangka kehidupan masyarakat yang dijadikan milik diri manusia dengan belajar (Abdullah, 2016)

Jadi, dapat disimpulkan bahwa hampir setiap aktivitas manusia merupakan budaya, seperti tindakan manusia dalam bermasyarakat tetap memerlukan proses pembelajaran. Dari berbagai arti di atas berkembanglah arti kebudayaan sebagai segala daya dan aktivitas manusia untuk mengolah dan mengubah alam.

\section{Etnomatematika}

Etnomatematika di Indonesia bukanlah suatu ilmu pengetahuan yang baru, melainkan sudah dikenal sejak adanya ilmu matematika itu sendiri. Hanya saja disiplin ilmu ini diketahui setelah beberapa ilmuwan memperkenalkan nama etnomatematika menjadi bagian dari ilmu matematika. Berkembangnya etnomatematika dikenal secara luas melalui kajian berbagai keilmuan yang saling berhubungan. Oleh sebab itu, telah banyak pengembangan etnomatematika terkhusus pada aplikasi pembelajaran di sekolah-sekolah

Istilah etnomatematika berasal dari kata ethnomathematics, yang diperkenalkan oleh D'Ambrosio seorang matematikawan Brasil pada tahun 1977 yang mendefinisikan etnomatematika sebagai berikut:

The prefix ethno is today accepted as a very broad term that refers to the social cultural context and therefore includes language, jargon, and codes of behavior, myths, and symbols. The derivation of mathema is difficult, but tends to mean to 


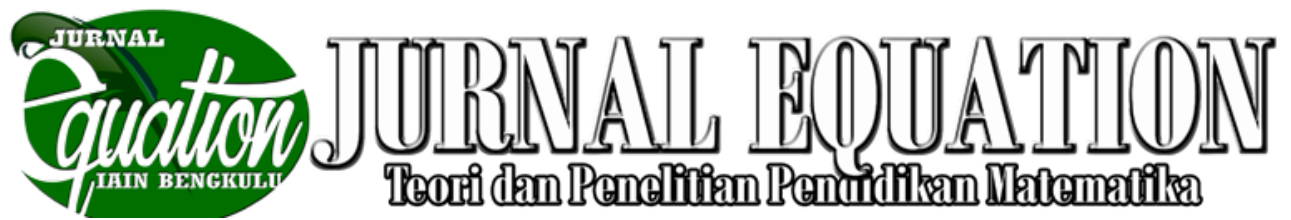

Volume 2 Nomor 2, September 2019, ISSN 2599-3291 (Cetak), ISSN 2614-3933 (Online)

explain, to know, to understand, and to do activities such as ciphering, measpauring, classifying, inferring, and modeling. The suffix tics is derived from techné, and has the same root as technique (Rosa \& Orey, 2011)

Etnomatematika tersusun dari kata ethno, mathema, dan tics. Awalan ethno mengarah pada konteks sosial dan budaya, seperti bahasa, jargon, dan tingkah laku, mitos, dan simbol. Asal muasal mathema sebenarnya sulit akan tetapi cenderung berarti menjelaskan, mengetahui, mengerti, dan melakukan aktivitas-aktivitas seperti menghitung, mengukur, mengklasifikasi, mengurutkan, dan memodelkan suatu pola yang muncul pada suatu lingkungan. Akhiran tics mengandung arti seni dalam teknik dan akar teknik.

Etnomatematika dapat diartikan sebagai matematika yag dipraktikkan oleh kelompok budaya, seperti masyarakat perkotaan dan pedesaan, kelompok buruh, anak-anak dari kelompok usia tertentu, masyarakat adat, dan lainnya (Zulkifli \& Dardiri, 2016).

Berdasarkan definisi tersebut, etnomatematika dapat diartikan sebagai terapan matematika pada budaya yang terkait dengan kegiatan matematika seperti berhitung, mengukur, merancang bangunan atau alat, bermain, menentukan lokasi, dan lain sebagainya.
Matematika yang timbul dan berkembang dalam masyarakat dan sesuai dengan kebudayaan setempat, merupakan pusat proses pembelajaran dan metode pengajaran. Hal ini membuka potensi pedagogis dengan mempertimbangkan pengetahuan para peserta didik yang diperoleh dari belajar di luar kelas. Dengan mengambil tema tertentu, pembelajaran matematika dapat dilakukan secara kontekstual sehingga akan memberikan pengalaman dan wawasan baru bagi peserta didik. Melalui etnomatematika pembelajaran akan lebih berkesan, karena sekaligus memperkenalkan tradisi maupun budaya lokal yang masih diakui dan dilakukan oleh kelompok masyarakat tertentu.

\section{Tari Kejei Khas Rejang Lebong}

Adat yang digunakan di Curup yaitu adat Rejang. Berbagai jenis kegiatan adat masyarakat Rejang Lebong, salah satunya pada ritual upacara Kejei dalam upacara adat rejang. Upacara Kejei adalah salah satu syarat wajib sebelum dilakukannya prosesi Tari Kejei. Tari Kejei pada awalnya merupakan Tari Klasik yang hanya dapat dinikmati oleh para keluarga kerajaan. Tetapi, sejalan dengan perkembangan zaman Tari Kejei bertransformasi menjadi Tari Tradisional yang dapat dinikmati semua kalangan. Ini dikarenakan, agar Tari Kejei tetap dapat dilestarikan oleh generasi ke generasi. 


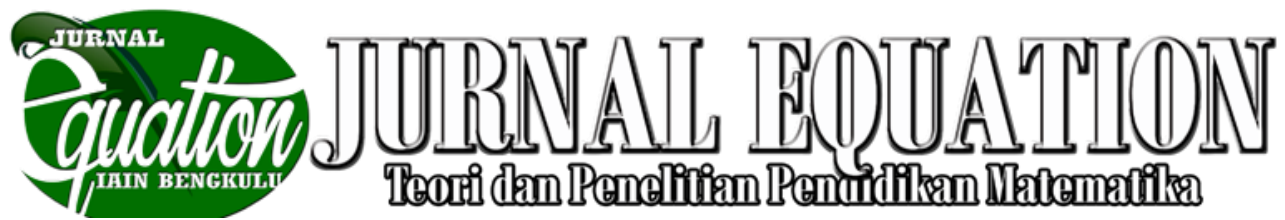

Volume 2 Nomor 2, September 2019, ISSN 2599-3291 (Cetak), ISSN 2614-3933 (Online)

Kejei berasal dari bahasa Rejang yang berarti suatu kerja atau perayaan besar. Tari Kejei merupakan hajatan bagi suku Rejang, karena yang mengadakan kejei tersebut merupakan orang-orang yang mampu, dengan pemotongan beberapa kerbau, kambing, atau sapi sebagai syarat sahnya upacara Kejei. Tari Kejei disajikan pada upacara penikahan dalam adat bimbang gedang (resepsi pernikahan) yaitu pada acara puncak resepsi pernikahan, yang kedua mempelai ikut serta dalam menarikan tarian ini, sebagai simbol pelepasan masa lajang kedua mempelai (Trizilia, 2014).

Tarian Kejei disajikan dengan diiringi alat musik tradisional berupa satu buah gong, lima buah kulintang dan satu buah redap. Seperangkat alat musik ini sangatlah penting keberadaannya. Bahkan sebelum memulai tarian, ada ritual khusus untuk penurunan alat musik dari tempat penyimpanan yang disebut temu'un gung klintang. Selain alat musik, tarian ini juga diiringi oleh beberapa lagu khas Rejang yang sebelumnya telah disepakati.

Tari Kejei merupakan tarian sakral yang memiliki aturan-aturan yang wajib dipatuhi dalam penyajian tari. Penari perempuan harus perawan dan dalam keadaan suci. Di saat penyajiaan terdapat dua sambei (menjelaskan aturan-aturan dalam bekejei) yang dibawakan oleh seorang penari laki-laki dan perempuan secara bersahutan. Ada sambei pangela (pembuka) dan sambei andak (penutup). Para penari juga harus berasal dari marga yang berbeda.

Dalam balai Kejei terdapat sebuah meja yang disebut dengan Penei. Penei berisikan hasil-hasil bumi Tanah Rejang. Penei merupakan lambang dari kemakmuran, yang terdiri dari (Trizilia, 2014): a) Setandan Pisang Emas, merupakan pisang yang diyakini masyarakat Rejang Lebong memiliki simbol kemakmuran, sebab pisang emas mempunyai isi yang gemuk dan rasanya manis. b) Daun Sirih, diyakini memiliki khasiat untuk menyembuhkan berbagai penyakit, seperti gatal-gatal, benjolan, dan penyakit lainnya. Masyarakat Rejang Lebong menjadikan sirih sebagai obat yang digunakan dalam kehidupan sehar-hari. c) Pinang dan Gagangnya, sama halnya seperti sirih, pinang juga diyakini memiliki kegunaan untuk mengobati penyakit, di antaranya bau mulut, bisul, dan lain-lain. d) Daun Setawar beserta batangnya, daun ini diyakini bisa mengusir roh-roh jahat. Dilakukan dengan memercikkan daun setawar yang diikat dalam beberapa jumlah yang telah direndam dengan air. e) Daun Sedingin dan batangnya, peran daun sedingin serupa dengan daun setawar yang dipercikkan secara bersama-sama untuk menghilangkan roh jahat. f) Tebu Sebatang, pengibaratan habis manis sepah dibuang juga sudah ada dalam bahasa Rejang sejak dulu 


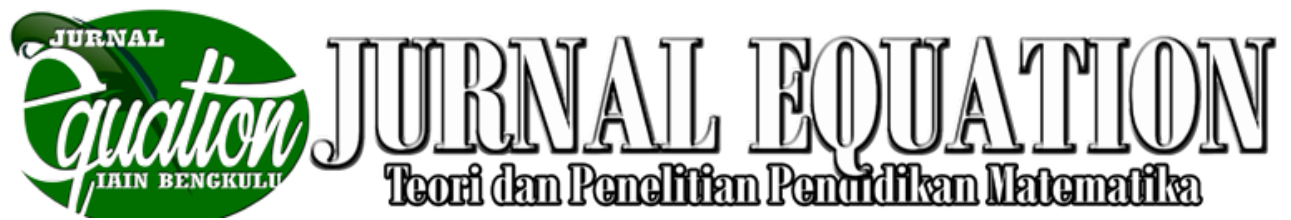

Volume 2 Nomor 2, September 2019, ISSN 2599-3291 (Cetak), ISSN 2614-3933 (Online)

abis dimu'mei ulek yang berarti ambil yang bagus buang yang jelek. Bila digeneralisasikan dalam pernikahan adalah bangun sifat yang baik tetapi dibuang sifat jelek. g) Batang Bambu, menggambarkan kekokohan dengan harapan kehidupan berumah tangga akan kokoh dan berguna kehidupannya nbagi orang lain. h) Buah Kundur, buah kundur diyakini akan mendatangkan kesejukan dalam berumah tangga. i) Beronang. Masyarakat Rejang Lebong pada umumnya berkebun. Ketika panen tiba, hasil panen diangkut dengan beronang sebagai alat bantu. j) Tampa, digunakan untuk membersihkan sisa-sisa ampas padi yang akan dimasak. Diharapkan pengantin bersih hidupnya. k) Selendang, merupakan ciri khas masyarakat Rejang Lebong, maka wajib ada di Penei. I) Payung Agung, disimbolkan untuk melindungi, Penei diletakkan di atas meja dan disusun di bawah payung. m) Tombak, Pedang, atau Keris, melambangkan keamanan karena tombak, pedang, dan keris merupakan senjata pusaka Rejang Lebong.

\section{METODE PENELITIAN}

Jenis penelitian ini adalah penelitian kualitatif dengan pendekatan fenomenologi. Penelitian kualitatif merupakan metode penelitian yang dilakukan secara utuh terhadap subjek penelitian yang terdapat pada suatu peristiwa. Sebagai metode ilmiah, fenomenologi merupakan jalan perumusan ilmu pengetahuan melalui tahap-tahap tertentu, dimana suatu fenomena yang dialami manusia menjadi subjek kajiannya (Hasbiansyah, 2008). Penelitian ini bertujuan untuk memahami eksplorasi etnomatematika sebagai jembatan antara matematika dan budaya (Tari Kejei) sehingga mendapatkan informasi yang lengkap.

\section{HASIL DAN PEMBAHASAN}

\section{Tari Kejei}

Berdasarkan hasil wawancara oleh Jauhari Kumara Dewi pada hari Selasa tanggal 5 Februari 2019 disampaikan bahwa Tari Kejei adalah tarian sakral yang diyakini masyarakat mengandung nilai-nilai mistik, sehingga hanya dilaksanakan masyarakat Rejang dalam acara menyambut para biku, perkawinan dan adat marga.

Tempat pementasan yang digunakan dalam Tari Kejei yaitu arena terbuka (panggung) yang dinamakan balai Kejei. Balai Kejei pada zaman dahulu didirikan kurang lebih seminggu sebelum acara itu dimulai, dibuat dengan cara bergotong royong. Balai Kejei adalah tempat yang dibuat khusus untuk tempat pelaksanaan semua prosesi Kejei. Setelah balai Kejei selesai didirikan, tugas diserahkan pada tuwei batin istilah dalam bahasa Rejangnya semreak kumat dan untuk bidang tugas di luar balai Kejei diserahkan 


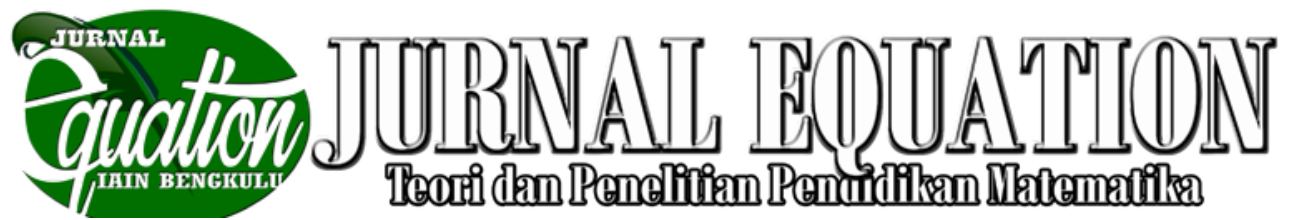

Volume 2 Nomor 2, September 2019, ISSN 2599-3291 (Cetak), ISSN 2614-3933 (Online)

kepada ginde di Curup (Herman Firnadi pada tanggal 5 Februari 2019).

\section{Hubungan Alat Musik Pengiring Kejei dengan Matematika}

Kekhasan Tari Kejei adalah alat-alat musik pengiringnya yaitu, kulintang, gong, dan redap. Dimana alat musik tersebut juga merupakan alat musik tradisonal Rejang Lebong yang dari zaman dahulu digunakan untuk mengiringi tarian sakral dan agung tersebut. Ketiga alat musik tersebut sangat berperan dalam tarian Kejei, oleh sebab itu sebelum tarian dimulai alat musik tersebut disyaratkan mengadakan ritual temu'un gung klintang.

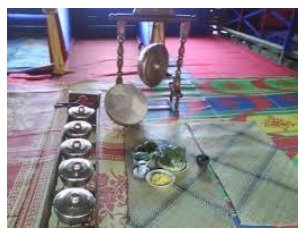

Gambar 1. Alat Musik Pengiring Tari Kejei.

Tabel 1.Hubungan antara Alat Musik Pengiring Tari Kejei dengan Matematika

\begin{tabular}{|c|l|l|}
\hline No & \multicolumn{1}{|c|}{ Alat Musik } & Konsep Matematika \\
\hline Kulintang & $\begin{array}{l}\text { Konsep matematika } \\
\text { yang digunakan } \\
\text { adalah bentuk } \\
\text { kulintang yang } \\
\text { menyerupai bangun } \\
\text { ruang yaitu tabung. } \\
\text { Stik kulintang juga } \\
\text { menggunakan } \\
\text { konsep tabung. }\end{array}$ \\
\hline
\end{tabular}

Sindi Destriani

Etnomatematika dalam seni...

\begin{tabular}{|l|l|l|}
\hline No & Alat Musik & $\begin{array}{l}\text { Konsep Matematika } \\
\text { menggunakan } \\
\text { konsep bangun } \\
\text { ruang balok. }\end{array}$ \\
\hline 2. & $\begin{array}{l}\text { Konsep matematika } \\
\text { yang digunakan } \\
\text { bentuk gong adalah } \\
\text { menyerupai bangun } \\
\text { ruang yaitu tabung. }\end{array}$ \\
\hline 3. & $\begin{array}{l}\text { Rodap } \\
\text { Gambar 3. Gong }\end{array}$ & $\begin{array}{l}\text { Konsep matematika } \\
\text { yang digunakan } \\
\text { redap adalah } \\
\text { menyerupai bangun } \\
\text { ruang yaitu tabung. }\end{array}$ \\
\hline
\end{tabular}

Konsep matematika yang ada pada alat musik pengiring Tari Kejei dapat digunakan untuk mengidentifikasi jari-jari, diameter, luas permukaan, serta volume suatu alat musik tersebut. Selain itu, konsep matematika juga dapat digunakan untuk menentukan berapa banyak bahan yang digunakan untuk pembuatan alat musik.

\section{Hubungan Gerakan Tari Kejei dengan}

\section{Matematika}

Tari Kejei ditarikan oleh pemudapemudi secara berpasang-pasangan dengan jumlah ganjil, seperti lima pasang, tujuh 


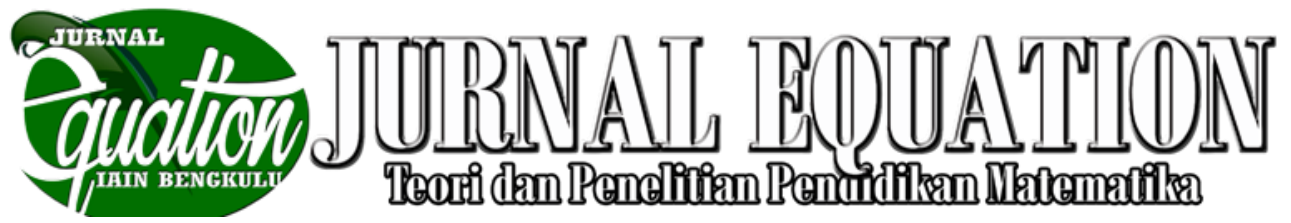

Volume 2 Nomor 2, September 2019, ISSN 2599-3291 (Cetak), ISSN 2614-3933 (Online)

pasang, sembilan pasang penari, dan seterusnya. Hal ini dikarenakan, menurut kepercayaan jumlah penari akan digenapkan oleh arwah nenek moyang yang akan ikut menari sebagai bentuk doa restu leluhur agar hidup damai, rukun, dan jauh dari mala bahaya. Jika ada hal yang menyimpang, maka leluhur tidak merestui acara gedang tersebut.

Jauhari Kumara Dewi menyampaikan dari hasil wawancara pada tanggal 6 Februari 2019, gerak yang dilakukan oleh penari perempuan tidak boleh terlalu gemulai, sehingga tarian terkesan sederhana yang mencerminkan sikap wanita Rejang yang sederhana. Gerakan yang dilakukan laki-laki harus tegas mencerminkan sikap gagah dan berwibawa.

Hasil revies video tarian Kejei pada tanggal 3 februari 2018, diperoleh beberapa gerakan tari, seperti :

1) Gerak sembah

Gerak sembah dilakukan sebanyak 3 kali, yaitu: sembah adat, sembah yang dilakukan untuk penghormatan kepada pengurus adat. Sembah tamu, sembah yang dilakukan untuk para tamu yang menghadiri acara. Serta, sembah pasangan menari, sembah yang dilakukan untuk perkenalan dan diajak menari.
Posisi gerak sembah yaitu duduk berlutut dengan pantat bertumpu di tumit kaki kiri, sedangkan kaki kanan dari lutut ke pergelangan kaki tegak lurus, serta kedua tangan diletakkan di atas lutut kaki kanan, dengan posisi kedua tangan dikembangkan kemudian ibu jari tangan ditemukan, serta kelima ujung jari menghadap kedepan.

Adapun ketukan dalam gerak sembah, yaitu sebagai berikut: Hitungan ke-1 dan 2, kedua telapak tangan dipertemukan; hitungan ke-3 dan 4, tangan dibawa ke atas di depan bahu dengan posisi masing-masing tangan dikepal dan ditemukan; hitungan ke-5 sampai 7, gerakan kedua jari tangan dibuka dan dikepal mengayun ke bawah; hitungan ke-8, mengembangkan kedua telapak tangan menghadap ke atas, di atas lutut kanan dan ujung jari kanan dan kiri dipertemukan. Sikap badan dan kepala sedikit dimiringkan ke kanan, agak ke depan derta pandangan lurus. Kemudian penari berdiri dan saling berhadapan memberi sembah, yang melambangkan pertemuan yang terjadi antara pria dan wanita.

2) Gerak beradap salah pinggang (penari pria) 


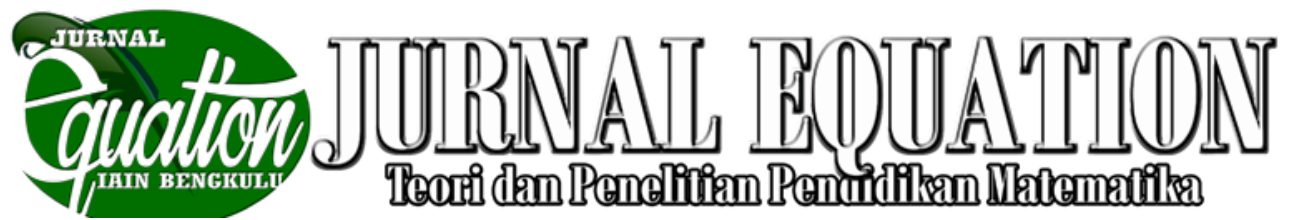

Volume 2 Nomor 2, September 2019, ISSN 2599-3291 (Cetak), ISSN 2614-3933 (Online)

Dimulai dengan berputar ditempat satu kali. Melangkah kaki kanan dan ditutup kaki kiri. Posisi kaki tegak lurus, kudua tangan terletak di perut samping kanan, kedua telapak tangan menghadap kebawah dan ujung jari tengah, jari telunjuk dan ibu jari saling bertemu. Poisi badan tegak lurus kedepan.

3) Gerak beradap salah pinggang (penari wanita)

Awal yang sama dengan penari putra yaitu berputar di tempat satu kali, dengan posisi tangan membuka menghadap kedepan berada di depan dada.

Adapun hitungan gerak beradap salah pinggang sebagai berikut: Hitungan ke-1-2, posisi kedua tangan diputar ke arah dalam dan posisi jari tengah ditemukan; hitungan ke-3, kedua tangan di bawa kesisi samping dengan posisi kedua tangan agak di muka dengan jarak $40 \mathrm{~cm}$ antara bahu dan pergelangan tangan; hitungan ke4, ujung jari tangan dilepaskan dengan posisi kedua telapak tangan menghadap keluar dan ujung jari menghadap ke atas setinggi bahu, dengan posisi badan tegak lurus, pandangan menghadap kepasangan, dan kepala tegak lurus, gerakan ini dilakukan berpasangan

4) Gerak tukar tempat

Gerakan bertukar tempat ini dilakukan dengan cara berjalan mengelilingi panei dimana penari pria memasuki area penari wanita dan penari wanita memasuki arena penari pria. Gerakan yang dilakukan adalah gerak elang menyongsong angin (penari wanita) dan gerak ngajak.

5) Gerak elang menyongsong angin (penari wanita)

Gerakan berjalan ditempat dimulai dari kaki kanan, kedua tangan berada disisi serong belakang dengan posisi tangan lurus ke bawah, telapak tangan menghadap ke bawah sambil memegang selendang.

6) Gerak ngajak (penari putra)

Gerak ngajak berarti mengajak yaitu gerakan membuka kedua telapak tangan di atas bahu yang berjarak 40 $\mathrm{cm}$, ujung jari menghadap ke atas sejajar dengan bahu, pada hitungan $3 \times 4$ melangkah memutar satu kali lingkaran empat penjuru. Kemudian penari kembali ke posisi semula dengan gerak elang menyongsong angin dan gerak ngajak.

7) Gerak patah dayung

Gerakan patah dayung pada tari kejei digunakan sebagai gerak 
Volume 2 Nomor 2, September 2019, ISSN 2599-3291 (Cetak), ISSN 2614-3933 (Online)

perpindahan, dengan berjalan di

tempat sebanyak delapan kali dimulai

dari kanan, posisi badan tegak lurus

dan menghadap ke pasangan penari.

Tabel 2.Hubungan antara Gerakan Tari Kejei dengan

Konsep Matematika

\begin{tabular}{|c|c|c|}
\hline No & Elemen Tari & Konsep Matematika \\
\hline 1. & Jumlah Penari & $\begin{array}{l}\text { Penari terdiri dari } \\
\text { penari wanita dan laki- } \\
\text { laki. Jumlah penari } \\
\text { masing-masing harus } \\
\text { ganjil, seperti tiga, lima, } \\
\text { dan seterusnya. Maka } \\
\text { jumlah penari adalah } \\
\text { tiga pasang, lima } \\
\text { pasang, dan } \\
\text { seterusnya. } \\
\text { Jumlah penari masing- } \\
\text { masing dapat } \\
\text { ditentukan dengan } \\
\text { menggunakan pola } \\
\text { bilangan ganjil, yaitu } \\
U_{n}=2 n-1, n \epsilon \text { bil.asli } \\
\end{array}$ \\
\hline 2. & $\begin{array}{l}\text { Gerak Sembah } \\
\text { Gambar 5. Gerak } \\
\text { Sembah }\end{array}$ & $\begin{array}{l}\text { Pada pola gerak, jika } \\
\text { ditarik garis lurus antara } \\
\text { pandangan mata, tangan, } \\
\text { dan posisi badan maka } \\
\text { akan terbentuk konsep } \\
\text { segitiga siku-siku }\end{array}$ \\
\hline
\end{tabular}

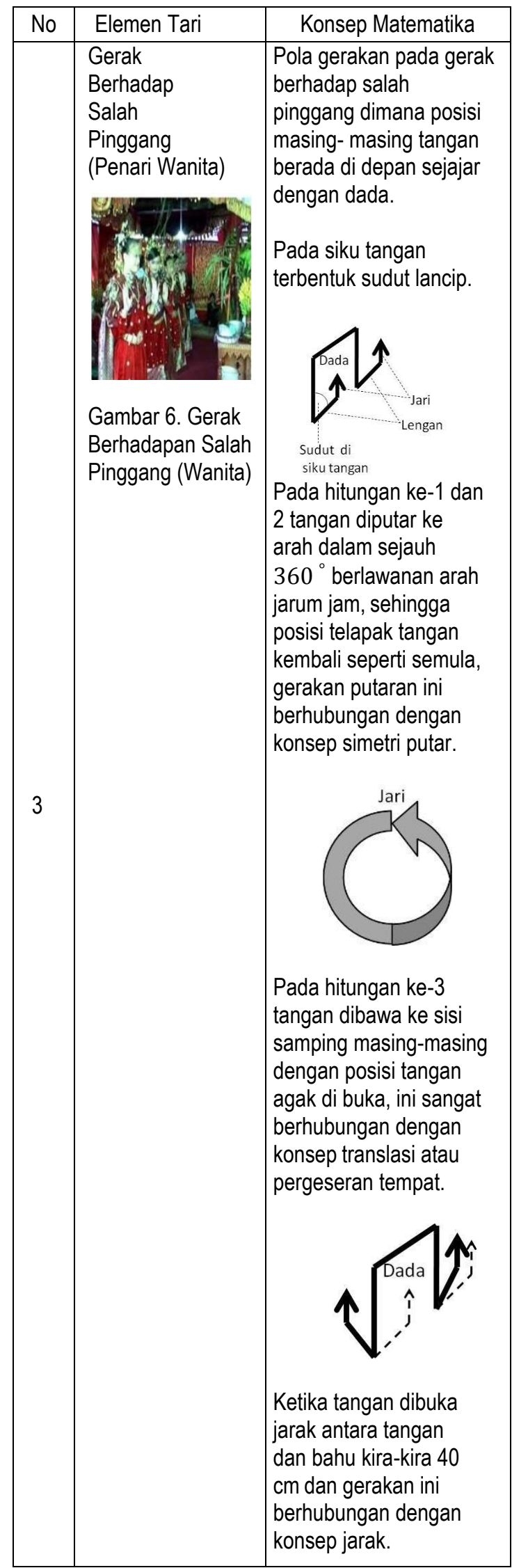


Volume 2 Nomor 2, September 2019, ISSN 2599-3291 (Cetak), ISSN 2614-3933 (Online)

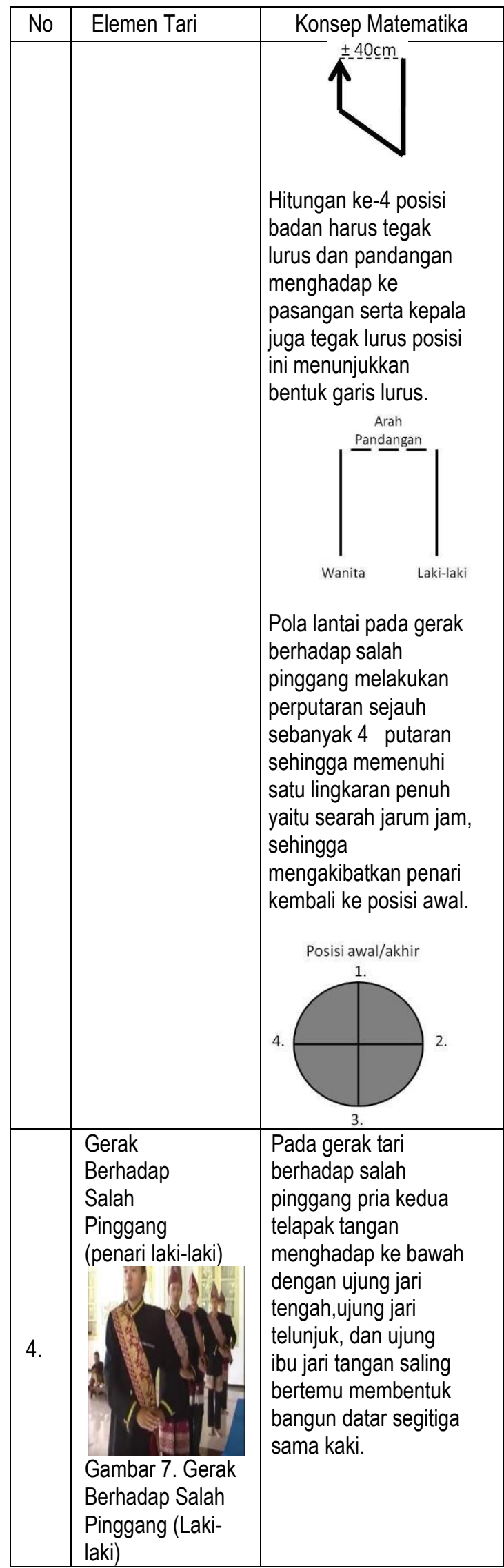

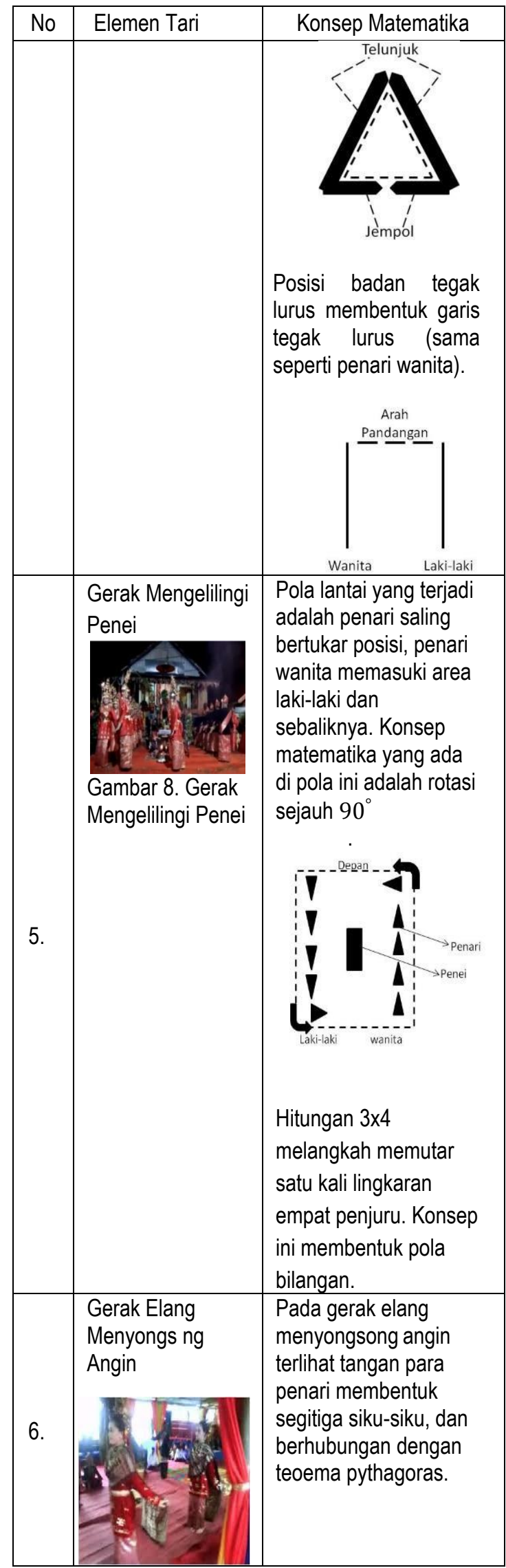


Volume 2 Nomor 2, September 2019, ISSN 2599-3291 (Cetak), ISSN 2614-3933 (Online)

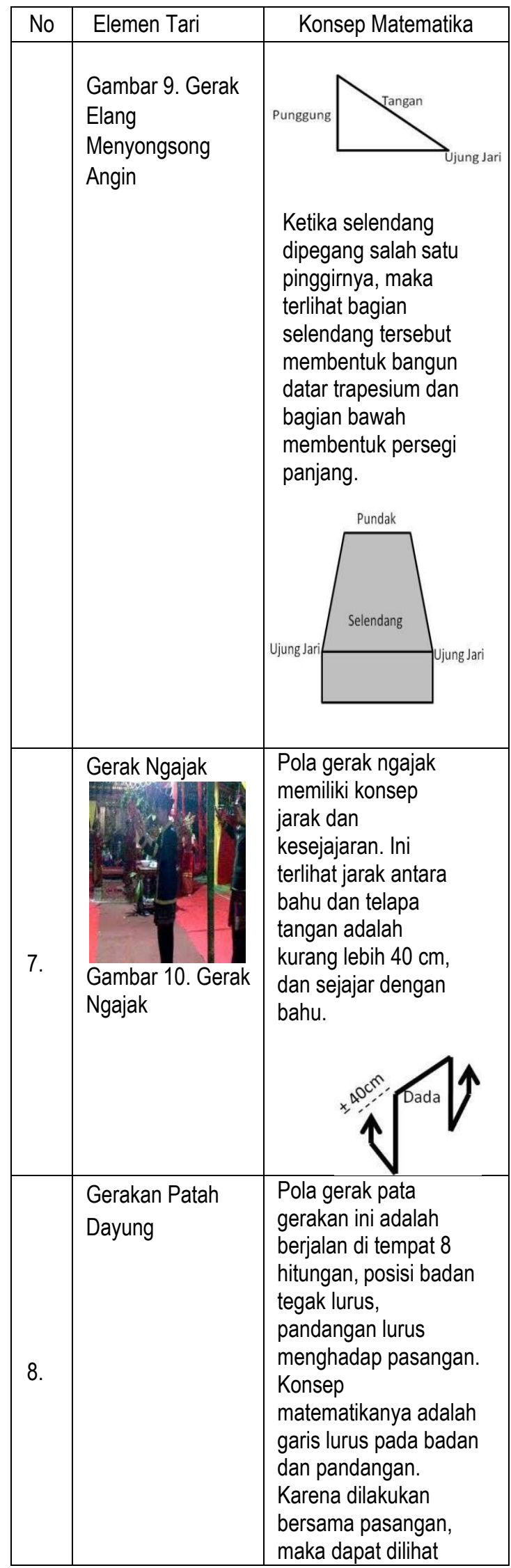

\begin{tabular}{|l|l|l|}
\hline No & Elemen Tari & \multicolumn{1}{|c|}{ Konsep Matematika } \\
\hline & & $\begin{array}{l}\text { kosep refleksi antara } \\
\text { penari wanita dan laki- } \\
\text { laki. }\end{array}$ \\
\hline 9. & Komposisi Penari & $\begin{array}{l}\text { Selalu membentuk } \\
\text { segiempat. }\end{array}$ \\
& & \\
& & \\
1 & \\
1
\end{tabular}

Hubungan antara pola gerak dan pola lantai Tari Kejei dengan matematika sangatlah erat, mulai dari ketukan hitungan gerak, posisi tangan yang saling sejajar, pandangan dan tubuh yang tegak lurus, posisi bentuk tangan ketika menari yang membentuk sudut lancip, bentuk segitiga samakaki, segitiga siku-siku, perputaran gerakan kaki (rotasi), dan komposisi penari yang membentuk bangun datar segiempat, pola hitungan yang digunakan pada ketukan gerakan tari, serta lainnya.

\section{PENUTUP}

\section{Kesimpulan}

Tari Kejei merupakan tari tradisional Kabupaten Rejang Lebong Provinsi Bengkulu. Tari Kejei ini memiliki beberapa elemenelemen pendukung seperti alat musik pengiring dan para penari (wanita dan lakilaki). Masing-masing elemen ini memiliki keterkaitan dengan konsep matematika. 


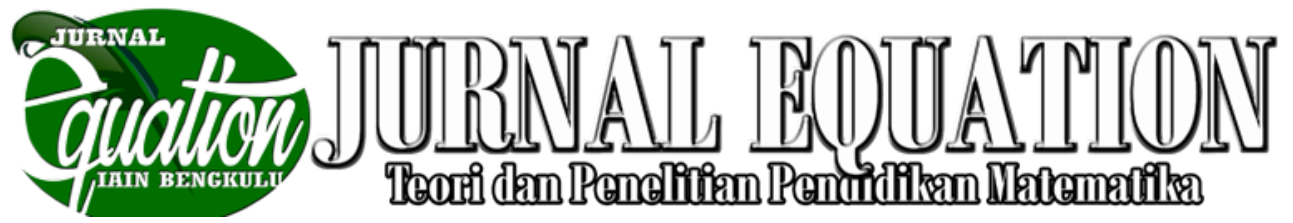

Volume 2 Nomor 2, September 2019, ISSN 2599-3291 (Cetak), ISSN 2614-3933 (Online)

Berdasarkan hasil penelitian diperoleh sebagai berikut:

1) Hubungan antara alat musik pengiring Tari Kejei dan matematika adalah bentuk alat musik yang menerapkan konsep bangun ruang yaitu tabung. Gong, Kulintang, dan Redap yang masingmasing menyerupai bentuk tabung dengan ukuran yang berbeda-beda. Konsep ini dapat digunakan untuk mengidentifikasi jari-jari, diameter, luas permukaan, serta volume suatu alat musik tersebut. Selain itu, juga dapat digunakan untuk menentukan berapa banyak bahan yang digunakan untuk pembuatan alat musik tersebut.

2) Hubungan antara gerakan Tari Kejei dan matematika adalah pola gerak dan pola lantai yang menerapkan konsep geometri diantaranya posisi tangan yang saling sejajar, pandangan dan tubuh yang tegak lurus, posisi bentuk tangan ketika menari yang membentuk sudut lancip, bentuk segitiga samakaki, segitiga sikusiku, perputaran gerakan kaki (rotasi), dan komposisi penari yang membentuk bangun datar segiempat, hingga pola hitungan yang digunakan pada ketukan gerakan tari.

\section{Saran}

Dari hasil penelitian yang telah diperoleh, penulis mengemukakan beberapa saran kepada beberapa pihak dalam rangka implementasi pembelajaran matematika berbudaya lokal yaitu Tari Kejei, tarian khas Kabupaten Rejang Lebong, diantaranya:

1) Guru

Agar menerapkan pembelajaran matematika berbasis budaya lokal dengan menjadikan Tari Kejei sebagai media pembelajaran agar siswa lebih tertarik untuk belajar matematika. Karena banyak hal yang dapat dikembangkan dari setiap unsur-unsur yang ada pada Tari Kejei. Salah satu konsep matematika yang dapat diajarkan adalah Geometri. Selain itu juga, secara tidak langsung guru memperkenalkan serta melestarikan kekayaan budaya yang dimiliki kepada generasi selanjutnya.

2) Peneliti Selanjutnya

Diharapkan untuk mengkaji Tari Kejei dari elemen lainnya, seperti busana dan tata rias penari serta hubungannya dengan matematika. Selain itu juga, peneliti selanjutnya dapat mengkaji keterkaitan matematika pada budaya khas Rejang Lebong lainnya.

\section{DAFTAR PUSTAKA}

Abdullah, A. A. (2016). Peran Guru dalam Mentransformasi. Seminar Matematika dan Pendidikan Matematika (p. 643). 


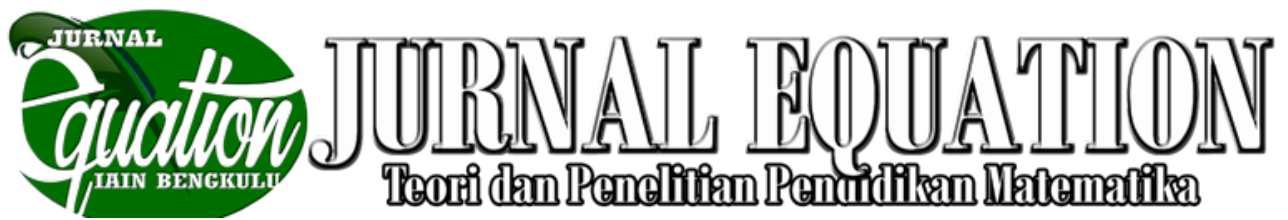

Volume 2 Nomor 2, September 2019, ISSN 2599-3291 (Cetak), ISSN 2614-3933 (Online)

Surakarta: Jurnal FKIP Universitas Negeri Surakarta.

Aksary, M. A. (2017). Analisis Desain Interior

Ruang Baca Perpustakaan Universitas

Patria Artha. Makassar: Fakultas Adab dan Humaniora UIN Alaluddin .

Anggita, S. (2018). Etnomatematika dalam

Pertunjukan Burok (Kesenian Tradisional

Rakyat Brebes). Seminar Nasional

Matematika dan Pendidikan Matematika

(p. 1). Purwokerto: Program Studi

Pendidikan Matematika FKIP Universitas

Muhammadiyah Purwokerto.

Astri Wahyuni, A. A. (2013). Peran Etnomatematika dalam Membangun karakter Bangsa. Penguatan Peran Matematika dan Pendidikan Matematika untuk Indonesia (p. 114). yogyakarta: Jurusan Pendidikan Matematika FMIPA.

Hasbiansyah, O. (2008, juni). Pendektan

Fenomenologi: Pengantar Praktik

Penelitian dalam IImu Sosial dan

Komunukasi. Vol.9 , p. 164.

Lestari, A. D. (2015). Review Buku Pengantar IImu Antropologi oleh

Prof.Dr.Koentjaraningrat. Yogyakarta:

Academia edu.

Lusi Nofitasari, Z. M. (2015). Keefektifan

Model Pembelajaran Tutor Sebaya

Bernuansa Etnomatematika Terhadap

Kemampuan Pemecahan Masalah

Peserta Didik pada Materi Segiempat.
Unnes Journal of Mathematics Education.

Mahanani, A. (2018). Upaya Meningkatkan Hasil Belajar Matematika Materi Pecahan di Kelas III SD Negeri 2 Wates. yogyakarta: Prodi Pendidikan Guru Sekolah Dasar FKIP UNY.

Pramusinta, A. (2013). Menurut Beberapa Ahli. Wordpress.

Prihandoko, A. C. (2005). Memahami Konsep Matematika Secara Benar dan Menyajikan dengan Menarik.

Dapartemen Pendidikan Nasional .

Puspadewi, I. G. (2016, Januari). Budaya dan Implikasinya Terhadap Pembelajaran Matematika. Jurnal Santiaji Pendidikan, Volume 6, Nomor $1,34$.

Puspitasari, N. (2016). Kontribusi Matematika Terhadap IImu Komputer di D3 Manajemen Informatika Politeknik Indonesia Surakarta. Informa Politeknik Indonusa Surakarta , 19.

Rahmawati, W. (2015). Pengembangan Media

Pembelajaran Melalui Multimedia

Autoplay untuk Peningkatan Hasil belajar

Siswa pada Mata pelajaran Sejarah

Kebudayaan Islam di Kelas X MAN II

Malang Kota Batu. Malang: Universitas

Islam Negeri Maulana Malik Ibrahim

Malang.

Rosa, M., \& Orey, D. C. (2011, Juni 16). Ethnomathematics: The Cultural Aspects 


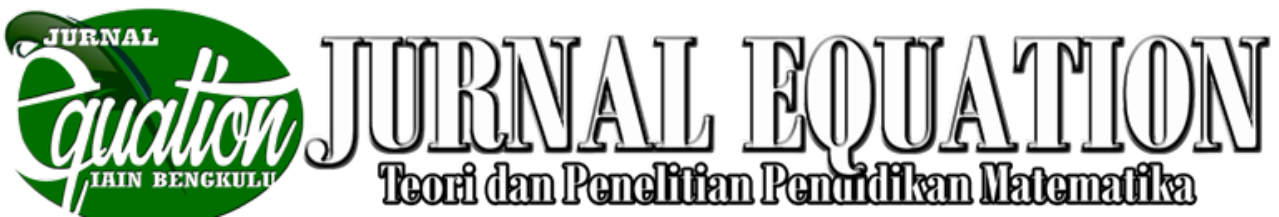

Volume 2 Nomor 2, September 2019, ISSN 2599-3291 (Cetak), ISSN 2614-3933 (Online)

of Mathematics. p. 32.

Setyawan, D. A. (2014). Ilmu Sosial Budaya

Dasar (ISBD). Solo: Wordpress.

Sugiyono. (2018). Metode Penelitian

Kuantitatif, Kualitatif dan $R$ \& $D$.

Bandung: Alfabeta.

Suherman, E., \& dkk. (2003). Strategi

Pembelajaran Matematika Kontemporer.

Bandung: Jurusan Pendidikan

Matematika, UPI.
Trizilia, E. K. (2014). Fungsi Tari Kejei pada Upacara Perkawinan di Curup Kabupaten Rejang Lebong Provinsi Bengkulu. Yogyakarta: Program Studi Pendidikan Seni Tari, FBS, UNY.

Zulkifli, M., \& Dardiri. (2016, Juli-Desember). Etnomatematika dalam Sistem Pembilangan pada Masyarakat Melayu Riau. Vol.19, p. 227. 